\title{
Temporal and spatial variation of rocky shores intertidal benthic communities in Southeast Brazil
}

\author{
Gabriela C. Zamprogno ${ }^{1}$, Flavio C. Fernandes ${ }^{2} \&$ Luiz L. Fernandes ${ }^{3}$ \\ 1. Universidade Federal do Espírito Santo, Programa de Pós-Graduação em Ciências Biológicas, Av. Marechal Campos, 1468, 29040-090, Vitória, ES, Brazil. (gczamprogno@gmail.com) \\ 2. Instituto de Estudos do Mar Almirante Paulo Moreira - IEAPM, Rua Kioto, 253, 28930-000, Arraial do Cabo, RJ, Brazil. (flaviocofe@yahoo.com) \\ 3. Universidade Federal do Espírito Santo, Departamento de Oceanografia e Ecologia, Av. Fernando Ferrari, 514, 29075-910, Vitória, ES, Brazil. (luiz.ufes@gmail.com)
}

\begin{abstract}
The relationships between environmental factors and temporal and spatial variations of benthic communities of three rocky shores of the state of Espírito Santo, Southeast Brazil, were studied. Sampling was conducted every three months, from August 2006 to May 2007, using intersection points. Chthamalus bisinuatus (Pilsbry, 1916) (Crustacea) and Brachidontes spp. (Mollusca) were the most abundant taxa, occupying the upper level of the intertidal zone of the rocky shore. The species richness was higher at the lower levels. The invasive species Isognomon bicolor (C. B. Adams, 1845) (Mollusca) occurred at low densities in the studied areas. The clustering analysis dendrogram indicated a separation of communities based on exposed and sheltered areas. According to the variance analyses, the communities were significantly different among the studied areas and seasons. The extent of wave exposure and shore slope influenced the species variability. The Setibão site showed the highest diversity and richness, most likely due to greater wave exposure. The communities showed greater variation in the lower levels where environmental conditions were less severe, relative to the other levels.
\end{abstract}

KEYWORDS. Midlittoral, wave exposure, benthos, Espírito Santo

RESUMO. Variação espaço-temporal das comunidades bentônicas do entremarés de costões rochosos no Sudeste do Brasil. Foram realizadas amostragens das comunidades bentônicas de médiolitoral em três costões rochosos do estado do Espírito Santo com o objetivo de estudar a variação espaço-temporal, relacionando com os fatores abióticos. Efetuaram-se coletas trimestrais entre agosto de 2006 e maio de 2007 , utilizando o método de pontos de interseção. Chthamalus bisinuatus Pilsbry, 1916 (Crustacea) e Brachidontes spp. (Mollusca) foram os táxons mais abundantes, ocupando os níveis superiores da zona entremarés dos costões. Nas zonas inferiores ocorreu um maior número de espécies. A espécie invasora Isognomon bicolor (C.B. Adams, 1845) (Mollusca) ocorreu em baixa cobertura nas áreas estudadas. O dendrograma indicou a separação das amostras das áreas expostas e abrigadas. Segundo os resultados das análises de variância, as comunidades foram significativamente diferentes entre as áreas e as estações do ano. O grau de exposição às ondas e a inclinação do costão influenciaram a variabilidade de espécies. Setibão apresentou os maiores índices de diversidade e de riqueza, provavelmente devido à maior exposição às ondas. As comunidades apresentaram maiores variações nos níveis inferiores, onde as condições ambientais são menos estressantes em relação aos outros níveis.

PALAVRAS-CHAVE. Médio litoral, exposição às ondas, bentos, Espírito Santo.

Intertidal rocky shores are heterogeneous environments that support a wide variety of organisms (ARAúso et al., 2005). These organisms are distributed in horizontal zones in which species are more abundant when environmental conditions favor their survival (Coutinho, 2002). The observation of these patterns has led to the development of various models of vertical zonation (ARAúJo et al., 2005). Although zonation is the main theme in many discussions of community structure, zonation alone does not explain the entire variability in distribution patterns of rocky shore populations (MenCONi et al., 1999).

Several physical variables (e.g., variations in the tidal levels, extent of wave exposure, slope of the shore and substrate heterogeneity) and biological parameters (e.g., predation, herbivory and competition) can influence the distribution of organisms in the intertidal zone (LITTLE \& Kitching, 1996; Raffaelli \& Hawkins, 1999; BenedettiCecchi et al., 2000b; Dethier \& Schoch, 2005; Murray et al., 2006). These factors determine the non-homogeneous spatial distribution of intertidal communities. The relative importance of these factors is difficult to define due to the high number of potential factors and the interactions among them (Little \& Kitching, 1996). Thus, all of these factors may create locally variable communities, representing differences on scales of centimeters to kilometers (SCHOCH \& DETHIER, 1996).
Rocky shores in Brazil are present almost exclusively in the south and southeast regions (Coutinho, 2002), and many studies have described the vertical distribution of benthic fauna and flora of these environments (OliveIRA-Filho \& MAYAL, 1976; SzÉCHY \& Paula, 2000; Coutinho, 2002; Oigman-Pszczol et al., 2004; MAsi et al., 2009). Although there are many studies on the benthic communities in Espírito Santo (SÁ \& Nalesso, 2000; Nassar et al., 2001; NAlesso et al., 2005; Costa \& Nalesso, 2006; Floeter et al., 2007), few reports have focused on the vertical distribution of the intertidal faunal and floral communities of the region.

Rocky shore organisms are subject to a variety of stresses, such as increasing air exposure, differences in the wave action and topography of the shore (CROwE et al., 2000), and anthropogenic impacts originating both from the land and sea, such as global changes in temperature, sea-level rise, an increased frequency of storms, changes in sediment loading (ThOMPson et al., 2002), and the introduction of exotic species (CROWE et al., 2000). Increases in temperature can negatively impact the performance and survival of marine organisms and drive important changes at the community level (HARLEY et al., 2006). The varied impacts on rocky shore environments further increase the importance of obtaining knowledge and monitoring native communities. The invasive 
bivalve Isognomon bicolor (C.B. Adams, 1845) is widely distributed on the Brazilian coast (DomANESCHI \& Martins, 2002; Fernandes et al., 2004; BrevesRAmos et al., 2010; ZAMProgno et al., 2010). This study aimed to describe and compare the seasonal variations in the midlittoral benthic communities of three rocky shores with different degrees of shore slope and wave exposure. The hypothesis of this study was that benthic communities will vary due to differences in wave action between exposed and sheltered shores.

\section{MATERIALS AND METHODS}

Study sites. This study was conducted in the coastal zone of the state of Espírito Santo, southeast Brazil. This area is characterized by crystalline Precambrian rocks in contact with Quaternary deposits (MARTin et al., 1996).

The winds are predominantly from the northeast and southeast. The northeast winds occur with greater frequency and are associated with the winds that blow during most of the year. In contrast, the southeast winds are more intense and associated with cold fronts that occur regularly at the littoral zone (AlBINo et al., 2001).

Samples were collected within a horizontal of 18 meters from each of three rocky shores at the three different beaches (Fig. 1): Costa beach, located near Vitória Bay and the Vitória port complex area $\left(20^{\circ} 19^{\prime} 44^{\prime \prime S}\right.$, $40^{\circ} 16^{\prime} 20^{\prime \prime} \mathrm{N}$ ), has a greater population density than the other areas; Setibão beach, which is located $37 \mathrm{~km}$ from
Costa beach (20 38'06'S, 40 $\left.25^{\prime} 28^{\prime \prime} \mathrm{N}\right)$; and Ubu beach, located approximately $62 \mathrm{~km}$ from Costa beach near the port of Ubu $\left(20^{\circ} 48^{\prime} 20^{\prime} \mathrm{S}, 40^{\circ} 35^{\prime} 15^{\prime}\right.$ 'N).

Sampling design. Sampling was performed quarterly at low tide at each shore between August 2006 and May 2007.

The topographic profile was obtained using the method of MUEHE (2002) employing a topographic level, graduated sight and a metric tape. Distances and differences between the ranges of two points in the profile were measured. Profiles were plotted using a compass. The profiling process consisted of adding the level shifts from the beginning of the profile to the maximum retreat of the wave during the survey. Using these data, it was possible to obtain the degree of shore inclination.

The characterization of the extent of exposure to waves was obtained indirectly according to LitTLE \& Kitching (1996) based on the observation of the direction of the prevailing winds and incident waves on the exposed face of the shore. Sites located in bays were sheltered against winds and currents and were considered protected sites, whereas sites that were directly facing the wind and incident waves were considered exposed, as suggested by SzÉCHY \& PAULA (2000).

The non-destructive method of determining percentage cover described by Sutherland (1974) was used to estimate the relative abundance of organisms. Within a horizontal extension of 18 meters

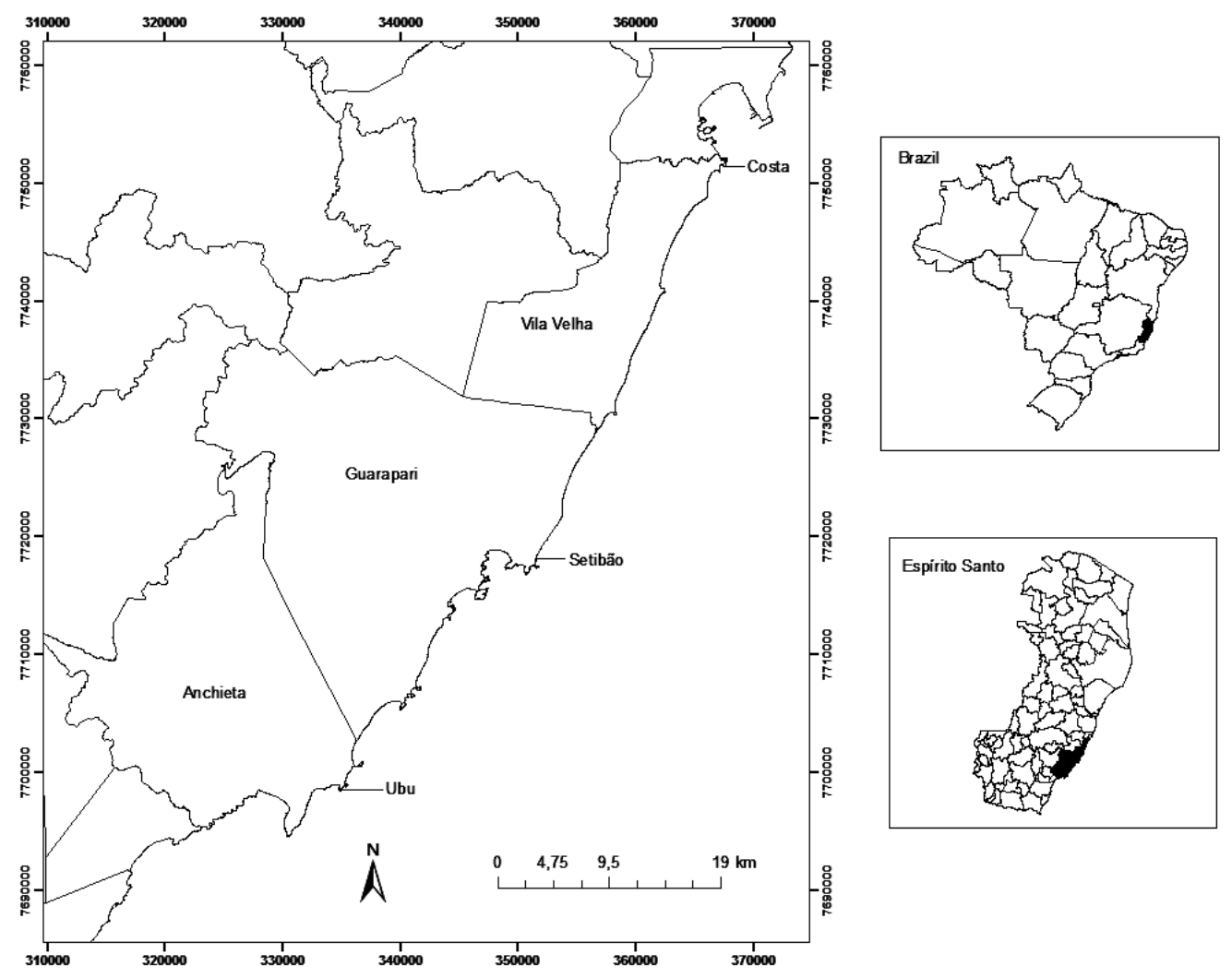

Fig. 1. The location of the study areas in the coastal zone, state of Espírito Santo, Southeast Brazil. 
on each shore, five vertical transects were randomly placed from the zone of Chthamalus bisinuatus to the beginning of the Sargassum spp. range (i.e., the beginning of the infralittoral zone), according to the limits of the midlittoral zone described by CoutinHo (2002). Contiguous samples were recorded taken in each $900 \mathrm{~cm}^{2}$ transect quadrat that was divided into 100 intersections, of which 30 intersections were randomly selected and marked. Individuals present below these intersections were identified to the lowest taxonomic level possible, with the 30 points corresponding to $100 \%$. Only the outer layer of the community was examined. The number of quadrats in each transect varied according to the inclination of the shore. At Costa beach, the midlittoral zone showed the smallest length (ranging from $2.4 \mathrm{~m}$ to $3.3 \mathrm{~m}$ ). In other areas, the length of the midlittoral zone ranged from $3.0 \mathrm{~m}$ to $4.2 \mathrm{~m}$. The air temperature was obtained in situ.

Analysis of the data. The relative abundance of species recorded in each transect was determined by the ratio between the summation of the percent cover of the quadrats and number of quadrats of the transect

The Kruskal-Wallis nonparametric test was used to detect differences in the relative abundance of each species among sites and differences in the air temperature among sites and periods. Significance was estimated using Monte Carlo resampling (10,000 runs).

The comparative analysis of areas for benthic associations included an analysis of clustering (dendrogram) using the Bray-Curtis coefficient based on the average relative abundance of species in each area and season calculated as the arc sen.

The permutation test analysis of similarity (ANOSIM) (one factor) was used to assess differences between groups defined by the cluster analysis. The transects (five) of each site and season were treated as replicates to increase the possibility of permutations and the power of the test (CLARKE \& WARWICK, 2001). The percentage of similarity procedure (SIMPER) was used to indicate those species that are mainly responsible for the differences identified in the results of the ANOSIM test (Clarke \& Warwick, 2001). A cumulative contribution of $80 \%$ was applied as in BOAVENTURA et al. (2002).

The Shannon-Wiener diversity index $\left(\log _{10}\right)$, Pielou evenness index and richness (number of taxa) were calculated for each transect. Significant differences among sites and seasons were tested using a two-factor analysis of variance (ANOVA). The Tukey's test was used a posteriori to assess the differences between pairs of means (ZAR, 1996). Assumptions of normality and variance in homogeneity were tested prior to all analyses using Kolmogorov-Smirnof and Levene's tests, respectively. For the number of taxa, it was necessary to transform the data with $\ln (\mathrm{x}+1)$. For all tests, $\alpha$ was equal to 0.05 .

\section{RESULTS}

Site characterization. The air temperature of each area is shown in Figure 2. Temperatures were higher during summer and lower in winter, as expected; however, significant differences between seasonal were not found. The Costa and Setibão beaches were considered exposed to wave action because they receive direct prevailing winds. Ubu beach was considered sheltered because it does not receive direct winds and waves from the northeast or southeast and is located in a bay. The shore of Costa beach had an inclination of $30^{\circ}$, whereas the other sites had inclinations of $27^{\circ}$.

Community characterization. Among the 34 taxa that were detected, 20 were recorded at Costa beach, and 27 at Setibão and Ubu beaches (Tab. I).

Arthrocardia flabellata (Kützing) Manza was identified as the dominant species of Corallinaceae articulated algae. However, other algae such as Corallina spp. and Amphiroa spp. were also observed.

Ubu and Setibão beaches showed the highest percentage of algae cover, occupying an average of $24 \%$ and $23 \%$ of the community, respectively, whereas algae occupied only $10 \%$ of the area at Costa beach.

The species Centroceras clavulatum, Dasya sp., Cladophoropsis sp., Padina gymnospora, Amphiroa sp. and Megabalanus sp. were restricted to Setibão beach, and Cladophora sp., Stramonita haemastoma, Zoanthus sp., and Palythoa sp. were recorded only at Ubu beach. The algae of the family Corallinaceae and the bivalve Brachidontes spp. and Isognomon bicolor occurred in greater abundance at Ubu beach relative to the other sites.

The average percentage of empty space in the rocky shores was higher at Costa beach $(6.4 \pm 0.41 \%)$, followed by Ubu beach $(5.09 \pm 1.5 \%)$ and Setibão beach $(3.5 \pm 1.3 \%)(p=0.01)$

Figure 3 shows the vertical distribution of benthic organisms from a transect in each area. A transect was selected by the occurrence of the largest number of species with an average abundance of greater than $2 \%$

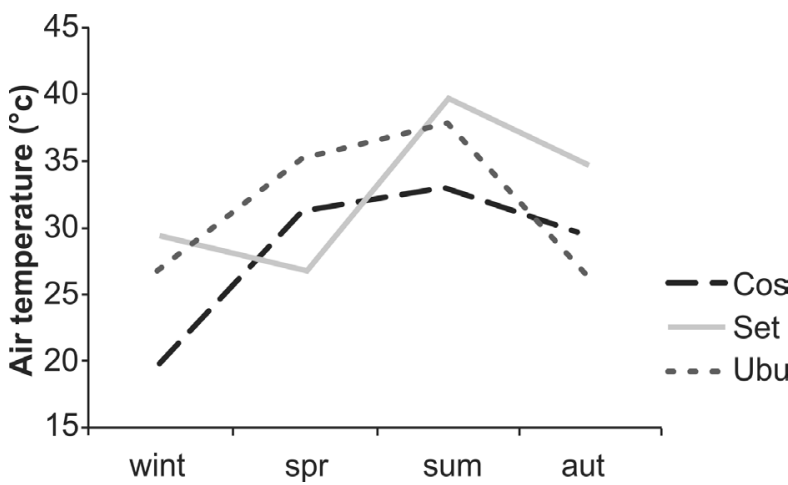

Fig. 2. The air temperature in each area and during each study period. Setibão (Set), Ubu and Costa (Cos) beach, state of Espírito Santo, Brazil, during the winter (win) and spring (spr) of 2006 and summer (sum) and autumn (aut) of 2007. 
Tab. I. A taxonomic list and average relative abundances $( \pm$ standard deviation $)(n=60)$ of the species recorded in the rocky shore of the Costa, Setibão and Ubu areas, state of Espírito Santo, Brazil. The result of the Kruskal-Wallis test is included $(\alpha=0.05)(P$, probability value associated with the test; NS, not significant).

\begin{tabular}{|c|c|c|c|c|}
\hline Taxa & Costa & Setibão & Ubu & $P$ \\
\hline \multicolumn{5}{|l|}{ CHLOROPHYCEAE } \\
\hline Anadyomene stellata (Wulfen in Jacq.) C. Agardh & $0.17 \pm 0.41$ & $0.01 \pm 0.05$ & $0.12 \pm 0.26$ & NS \\
\hline $\begin{array}{l}\text { Centroceras clavulatum (C. Agardh in Kunth) Mont. in Durieu de } \\
\text { Maisonneuve }\end{array}$ & 0 & $3.83 \pm 9.27$ & 0 & 0.02 \\
\hline Chaetomorpha antennina (Bory) Kützing & $1.31 \pm 1.57$ & $0.93 \pm 0.88$ & $0.38 \pm 0.86$ & 0.003 \\
\hline Cladophora sp. & 0 & 0 & $1.78 \pm 2.82$ & $<0.001$ \\
\hline Cladophoropsis sp. & 0 & $2.48 \pm 6.54$ & $0.04 \pm 0.17$ & 0.007 \\
\hline Codium sp. & 0 & 0 & $0.01 \pm 0.04$ & NS \\
\hline Ulva spp. & $0.92 \pm 2.00$ & $4.95 \pm 6.00$ & $0.56 \pm 0.48$ & $<0.001$ \\
\hline \multicolumn{5}{|l|}{ PHAEOPHYCEAE } \\
\hline Colpomenia sinuosa (Roth) Derbès \& Solier & $0.12 \pm 0.36$ & $0.28 \pm 0.49$ & $0.26 \pm 0.69$ & NS \\
\hline Padina gymnospora (Kützing) Sond. & 0 & $0.06 \pm 0.26$ & 0 & NS \\
\hline Sargassum spp. & $1.10 \pm 1.54$ & $1.13 \pm 1.45$ & $1.59 \pm 2.27$ & NS \\
\hline \multicolumn{5}{|l|}{ RHODOPHYCEAE } \\
\hline Acrosorium sp. & $0.23 \pm 0.79$ & $2.49 \pm 3.18$ & $0.14 \pm 0.35$ & $<0.001$ \\
\hline Amphiroa sp. & 0 & $0.11 \pm 0.28$ & 0 & NS \\
\hline Corallinaceae articulated & $5.68 \pm 4.84$ & $5.22 \pm 4.62$ & $13.01 \pm 5.06$ & $<0.001$ \\
\hline Corallinaceae fouling & $0.36 \pm 0.71$ & $0.59 \pm 1.37$ & $3.18 \pm 2.72$ & $<0.001$ \\
\hline Dasya sp. & 0 & $0.05 \pm 0.12$ & 0 & NS \\
\hline Hypnea spinella (C. Agardh) Kützing & $0.02 \pm 0.08$ & $0.21 \pm 0.62$ & $2.13 \pm 5.20$ & NS \\
\hline Ochtodes secundiramea (Mont.) M. Howe & 0 & $2.10 \pm 5.22$ & $0.17 \pm 0.51$ & 0.001 \\
\hline \multicolumn{5}{|l|}{ CNIDARIA } \\
\hline Palytoa sp. & 0 & 0 & $0.56 \pm 1.55$ & 0.008 \\
\hline Zoanthus sp. & 0 & 0 & $0.29 \pm 0.52$ & 0.001 \\
\hline \multicolumn{5}{|l|}{ MOLLUSCA } \\
\hline Brachidontes spp. & $25.75 \pm 5.47$ & $31.22 \pm 8.05$ & $35.55 \pm 7.08$ & $<0.001$ \\
\hline Crassostrea rhizophorae (Guilding, 1828) & $0.04 \pm 0.16$ & 0 & $0.03 \pm 0.08$ & NS \\
\hline Collisella subrugosa (Orbigny, 1846) & $2.21 \pm 1.40$ & $0.91 \pm 0.84$ & $0.84 \pm 0.75$ & $<0.001$ \\
\hline Fissurella spp. & $0.36 \pm 0.72$ & $0.33 \pm 0.34$ & $0.12 \pm 0.25$ & 0.045 \\
\hline Isognomon bicolor (C. B. Adams, 1845) & $1.68 \pm 1.01$ & $2.17 \pm 1.30$ & $3.40 \pm 1.00$ & $<0.001$ \\
\hline Leucozonia nassa (Gmelin, 1791) & 0 & $0.04 \pm 0.09$ & $0.01 \pm 0.05$ & NS \\
\hline Littorina ziczac Gmelim, 1791 & $1.07 \pm 0.84$ & $1.01 \pm 0.73$ & $0.86 \pm 0.52$ & NS \\
\hline Perna perna (Linnaeus, 1758) & $12.74 \pm 6.15$ & $1.35 \pm 1.78$ & 0 & $<0.001$ \\
\hline Siphonaria hispida E. A. Smith, 1890 & 0 & $0.03 \pm 0.10$ & $0.30 \pm 0.30$ & $<0.001$ \\
\hline Stramonita haemastoma (Linnaeus, 1767) & 0 & 0 & $0.01 \pm 0.05$ & NS \\
\hline \multicolumn{5}{|l|}{ ANNELIDA } \\
\hline Phragmatopoma sp. & $1.80 \pm 2.56$ & $3.26 \pm 3.03$ & 0 & $<0.001$ \\
\hline \multicolumn{5}{|l|}{ CRUSTACEA } \\
\hline Chthamalus bisinuatus Pilsbry, 1916 & $34.27 \pm 5.56$ & $30.95 \pm 11.81$ & $30.21 \pm 8.82$ & NS \\
\hline Megabalanus sp. & 0 & $0.05 \pm 0.10$ & 0 & 0.03 \\
\hline Tetraclita stalactifera (Lamarck, 1818) & $3.73 \pm 2.02$ & $1.27 \pm 1.68$ & $0.14 \pm 0.20$ & $<0.001$ \\
\hline \multicolumn{5}{|l|}{ ECHINODERMATA } \\
\hline Echinometra lucunter Linnaeus, 1758 & $0.14 \pm 0.23$ & 0 & $0.06 \pm 0.11$ & 0.018 \\
\hline
\end{tabular}

in each area. The species with a lower average cover that occurred in the analyzed transects were grouped as "other invertebrates" or "other algae".

In general, the higher levels of the shore were dominated by Brachidontes spp. and Chthamalus bisinuatus. A larger number of taxa occurred in the lower levels relative to the upper levels. Among the algae, the articulated Corallinaceae was more abundant in all areas. Algae occurred in the lower levels, except for Ulva spp. and Ochtodes secundiramea, which at Setibão beach also occurred at the higher levels (Fig. 3).

At Costa beach, Collisella subrugosa, Isognomon bicolor and Littorina ziczac, classified as other invertebrates in Fig. 2, occurred mainly at the higher levels. The articulated Corallinacea algae and the Tetraclita stalactifera and Perna perna invertebrates were very abundant in the lower levels.

At Setibão beach, a greater number of species occurred with an average abundance greater than 2\%. Although Cladophoropsis sp. and Centroceras clavulatum algae had an average abundance of greater than $2 \%$, they were not represented in Fig. 3 to permit a better graphic representation of the transect. Isognomon bicolor occurred at the higher levels. For 
the taxa classified as "other invertebrates" in Fig. 3, i.e., Collisella subrugosa, Fissurella sp. and Littorina ziczac, also occurred at the higher levels, while Perna perna and Tetraclita stalactifera were recorded in the lower levels. Articulated Corallinacea algae, Acrosorium sp. and the polychaete Phragmatopoma sp. were more abundant at the lower levels.

At Ubu beach, Isognomon bicolor, Collisella subrugosa and Littorina ziczac occurred at higher levels. Corallinacea and Hypnea spinella of the algae family were the taxa more abundant at lower levels (Fig. 3).

Multivariate analysis. The cluster analysis with a similarity of $73 \%$ resulted in the formation of two main groups. Group 1 included samples from exposed shores (Setibão and Costa beaches), and group 2 included samples from the sheltered shore (Ubu beach) (Fig. 4). The analysis of similarity (ANOSIM) revealed significant differences between groups 1 and $2(\mathrm{R}=$ $0.609, \mathrm{p}=0.001)$.

The SIMPER analysis defined the species that had the greatest contribution to the similarity within groups relative to the sampling sites. The taxa Chthamalus bisinuatus and Brachidontes spp. contributed most to the similarity within groups in the three areas. The average similarity was highest at Costa beach (82.42) and lowest at Setibão beach (72.95).

The dissimilarity between the samples of Setibão and Ubu beaches was mainly determined by Phragmatopoma sp., which did not occur in Ubu, and articulated Corallinaceae, which had a higher abundance in Ubu. Perna perna, with a higher abundance at Costa beach, and Ulva sp., with a higher abundance in Setibão beach, contributed most to the separation between the samples of these two beaches. The average dissimilarity between each pair of group combinations was higher among the samples of Costa and Ubu beaches (35.82. The species that occurred in the lower levels had the greatest contribution to the site differentiation.

Univariate analysis. Setibão beach presented the highest average diversity value $(0.74 \pm 0.12)( \pm$ standard deviation), followed by Costa beach $(0.73 \pm 0.06)$ and Ubu beach $(0.68 \pm 0.10)$ (Fig. 5). According to the Tukey test, the diversity of Setibão was significantly different from that of Ubu. For the different seasons, the lowest

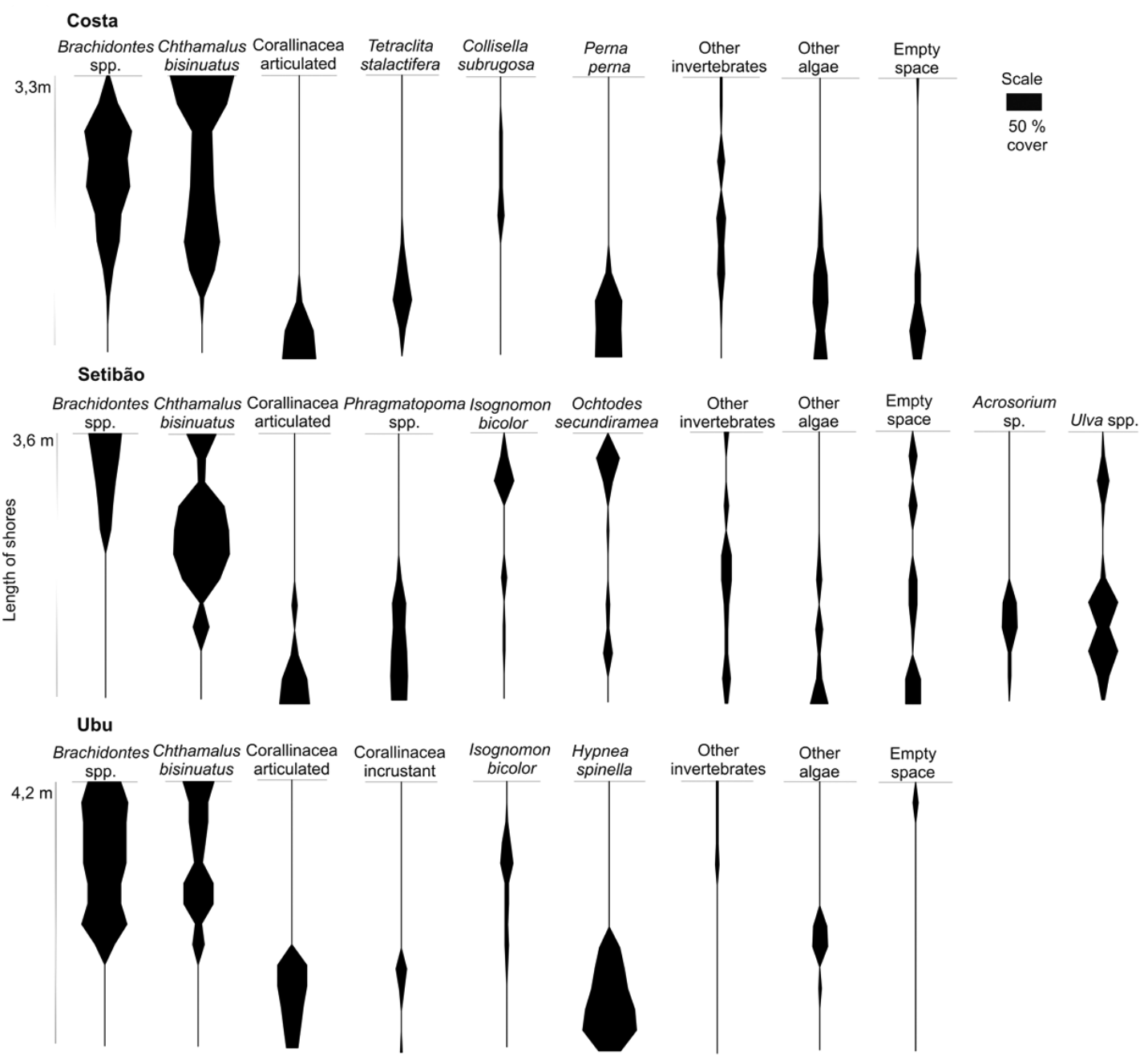

Fig. 3. The vertical distribution of the most representative species detected on the rocky shore of the midlittoral zones of Costa, Setibão and Ubu beaches. 


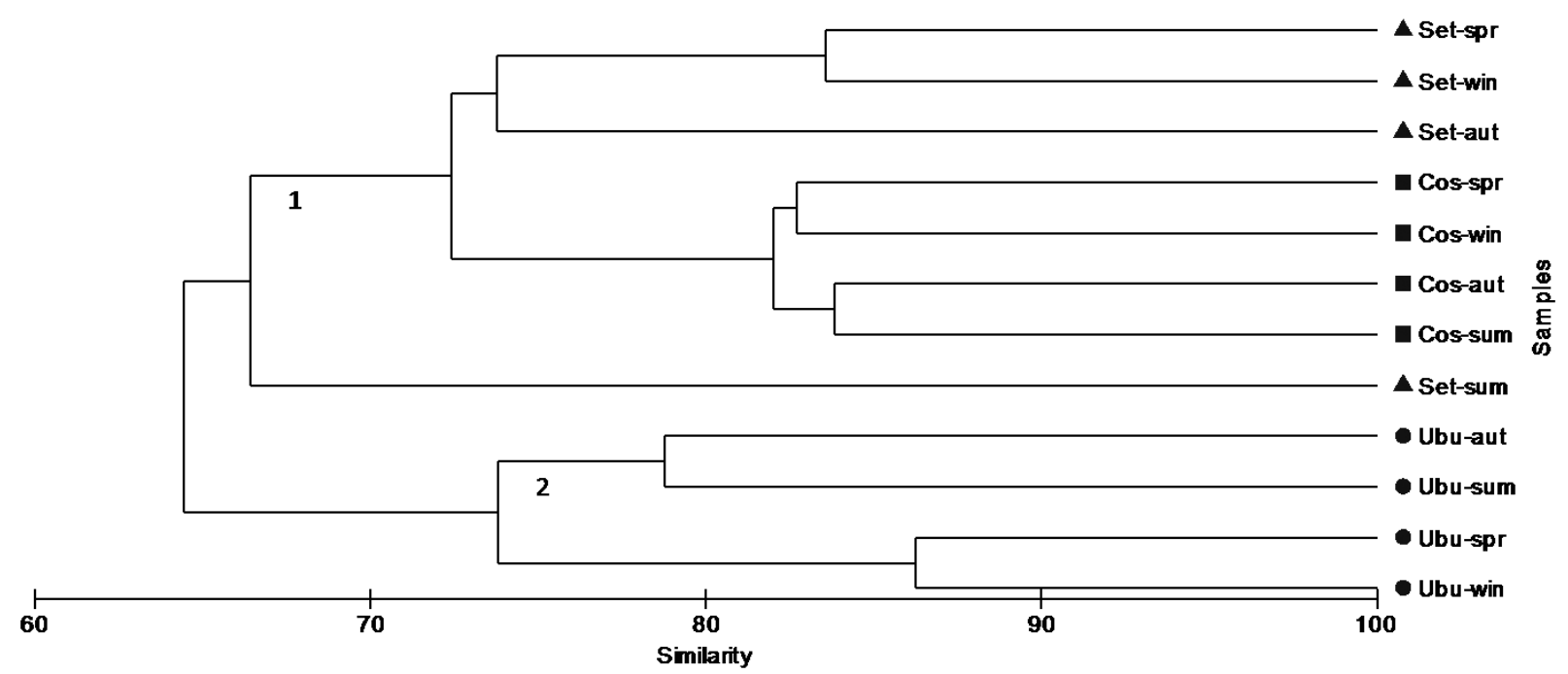

Fig. 4. Analysis of the benthic community groups based on the transformed (fourth root) average relative abundances for species in each area and season (Bray-Curtis coefficient). Setibão (Set), Ubu and Costa (Cos) beaches, state of Espírito Santo, Brazil, in the winter (win) and spring (spr) of 2006 and summer (sum) and autumn (aut) of 2007.

average value $(0.64 \pm 0.06)$ was recorded in the spring and was significantly different from those recorded in the summer $(0.75 \pm 0.07)$ and autumn $(0.76 \pm 0.06)$. There was no significant difference in the interaction between sites and seasons for this index (Tab. II).

The benthic community of Costa beach had the highest average evenness value $(0.70 \pm 0.05)$ and was different from the other areas (evenness values of 0.64
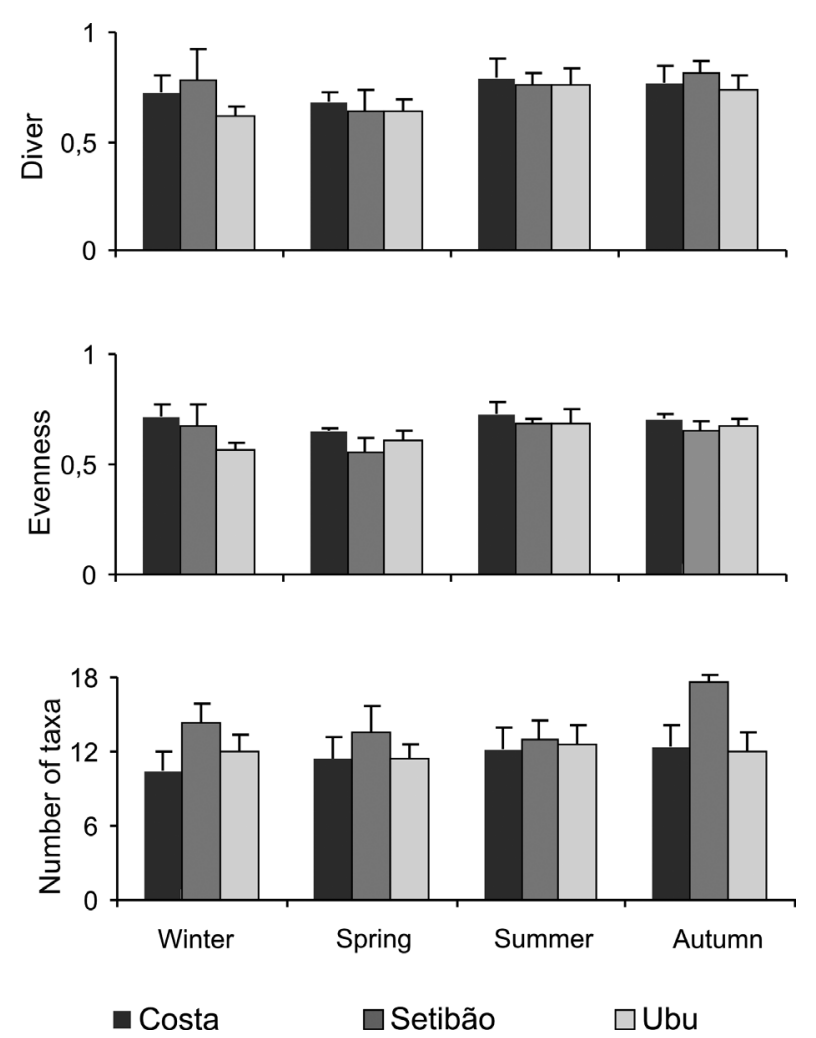

$\square$ Ubu

Fig 5. Mean values ( \pm standard deviation) of the diversity indices, evenness and richness (number of taxa) of the benthic communities of the midlittoral zones at the Costa, Setibão and Ubu areas, state of Espírito Santo, Brazil, between July 2006 and May 2007. \pm 0.11 and of $0.63 \pm 0.08$ for Setibão and Ubu beach, respectively). The lowest mean value $(0.59 \pm 0.05)$ was recorded in the spring and was significantly different from the summer $(0.69 \pm 0.05)$ and autumn $(0.67 \pm 0.03)$ values. The interaction test for this index showed the existence of significant differences (Tab. II).

The mean richness was higher at Setibão beach $(14.65 \pm 2.53)$ and was significantly different from the other areas. Ubu and Costa beach had average mean richness values of $11.90 \pm 1.45$ and $11.50 \pm 1.97$, respectively. Autumn had the highest mean value (13.93 \pm 2.96 ), whereas spring had the lowest richness (12.06 $\pm 1.90)$. Significant differences were found between the interactions (site and season) (Tab. II).

\section{DISCUSSION}

Rocky shore organisms are subjected to a natural vertical gradient of increasing physical stress with increased exposure to air (i.e., higher on the shore) due to variations in tidal levels (CROwE et al., 2000). Consequently, a greater shore height results in a lower species richness (DAVIDSON, 2005) and greater species dominance (BoAventura et al., 2002). The higher midlittoral levels in this study are dominated by Brachidontes spp. and Chthamalus bisinuatus. This result was also reported in other studies of the Brazilian coast (Oliveira-Filho \& Mayal, 1976; Coutinho, 2002; MASI et al., 2009), demonstrating that these genera are tolerant to stress at the shore. The physical stress due to desiccation is decreased lower on the shore, corresponding to a larger number of recorded species.

According to CoutinHo (2002), higher midlittoral levels are predominantly occupied by Chthamalus bisinuatus, whereas Tetraclita stalactifera occupies the middle midlittoral zone and Megabalanus sp. occupies the upper zone of the infralittoral zone. This distribution 
Tab. II. Results of a two-factor ANOVA using diversity indices, evenness and richness data for the Costa, Setibão (Set) and Ubu areas, state of Espírito Santo, Brazil, and the seasons (winter and spring of 2006 and summer and autumn of 2007). The richness values were transformed by $1 \mathrm{n}$ $(\mathrm{x}+1)$. The homogeneous groups determined by the Tukey test were ranked from lowest to highest averages $(\mathrm{F}$, test value; $P$, probability value associated with the test, $\alpha=0.05$; NS, not significant).

\begin{tabular}{|c|c|c|c|c|c|}
\hline Variable & Source of variation & Degrees of freedom & $\mathrm{F}$ & $P$ & Tukey HSD \\
\hline \multirow[t]{3}{*}{ Diversity } & site & 2 & 3.932 & 0.026 & Ubu Cos Set \\
\hline & season & 3 & 7.798 & $<0.001$ & $\mathrm{Sp} \mathrm{W} \mathrm{Su} \mathrm{A}$ \\
\hline & site $\mathrm{x}$ season & 6 & 1.447 & NS & \\
\hline \multirow[t]{3}{*}{ Evenness } & site & 2 & 7.555 & $<0.001$ & $\underline{\text { Ubu Set }} \underline{\operatorname{Cos}}$ \\
\hline & season & 3 & 8.172 & $<0.001$ & Sp W Su A \\
\hline & site $\mathrm{x}$ season & 6 & 2.506 & 0.034 & \\
\hline \multirow[t]{3}{*}{ Richnness } & site & 2 & 18.589 & $<0.001$ & $\underline{\text { Cos Ubu Set }}$ \\
\hline & season & 3 & 3.413 & 0.025 & $\underline{\mathrm{Sp} \mathrm{W} \mathrm{Su} \mathrm{A}}$ \\
\hline & site $\mathrm{x}$ season & 6 & 2.331 & NS & \\
\hline
\end{tabular}

was also observed in this study for $C$. bisinuatus and T. stalactifera in all areas. However, Megabalanus sp. occurred at the lower levels of the midlittoral only at Setibão beach. This occurrence can be attributed to the possibility that species in exposed locations may occupy higher levels due to the high reach of spraying water, thereby reducing the physical stress during periods of low tide (UNDERWOOD, 1981).

The invasive bivalve Isognomon bicolor occurred only in the intermediate midlittoral level and presented reduced average abundance in comparison with the study of Arraial do Cabo (Fernandes et al., 2004), in which the organisms were distributed in the lower midlittoral and in the infralittoral zone. In this study, this species occurred at all sites and all seasons of the year, showing its stabile establishment in the studied region. In many cases, the introduction of an exotic species has no dramatic influence on marine communities (CROWE et al., 2000). However, the absence of previous studies in the sampled areas impedes the verification of the adverse impact of an invasive species on the native community. According to FERNANDES et al. (2004), it is possible that I. bicolor competes for space and food with the mussel $P$. perna. In Santos Bay, the two species occupy the same area with $I$. bicolor commonly adhering to the byssus of $P$. perna (CASARINI \& HENRIQUes, 2011). In this present study, the two species occupied different levels of the midlittoral zone with I. bicolor occurring at higher levels, demonstrating a lack of competition for space between these species. However, future monitoring is necessary to further examine this phenomenon.

Rocky shore organisms are subject to a horizontal gradient of physical stress due to differences in wave action (CROwE et al., 2000). The difference between the intertidal communities of exposed and sheltered areas, as demonstrated by several authors (OLIVEIRA-FILHO \& MaYal, 1976; McQuaid \& Branch, 1984; McQuaid \& Lindsay, 2000; Branch \& StefFani, 2004; Araújo et al., 2005), also occurred in this study as demonstrated by the clustering analysis. The impact of waves is also an important factor influencing the intertidal benthic communities (LitTle \& Kitching, 1996; BARRETO, 1999; Branch \& StefFani, 2004; Araújo et al., 2005). Sibaja-
CORDERO \& CORTÉS (2008) concluded that the interaction between species (predation and space monopolization) was a possible cause of differences in abundance between wave-exposed and sheltered areas.

Filter-feeding organisms are well-suited for exposed conditions due to increased food supply (Raffaelli \& Hawkins, 1999). In the studied areas, Perna perna occurred only on exposed shores. BOAVENTURA et al. (2002) noted that along the Portuguese coast, mussels also occur in the lower portion of the midlittoral zone of the most exposed sites, which is in agreement with our study. Phragmatopoma sp. is also restricted to the exposed coast and most frequently found in these environments (SZÉCHY \& Paula, 2000; Masi \& Zalmon, 2008).

The macroalgae Chaetomorpha antennina occurred at the three sites but at a greater abundance in the exposed areas, and Centroceras clavulatum was recorded only at Setibão beach. Algae are common in areas subjected to strong wave impacts (OliveIRA-Filho \& MaYAL, 1976; SzÉCHY \& PAula, 2000; Coutinho, 2002).

For certain species, feeding processes, such as foraging or predation, may be more difficult at exposed sites (RAFFAELli \& HAWKINS, 1999). The predator Stramonita haemastoma occurred only on sheltered coasts at a low percentage. According to Menge \& SuTHERLAND (1976), predators such as gastropods are rare exposed area and confined to crevices. Thus, the lack of analysis of crevices may explain their observed absence on the exposed coast in this study.

The data from this study were similar to those of ZAMPROGNO et al. (2010), showing that Isognomon bicolor occurs at a low abundance in the rocky shores of the state of Espírito Santo, contrary to the findings of Breves-Ramos et al. (2010) for Rio de Janeiro. However, when comparing the three sampling locations, I. bicolor occurred in a greater percentage at Ubu beach, a sheltered area. According to CASARIni \& Henriques (2011), the lowest densities of this species are found in exposed locations. Branch \& SteFFAni (2004) observed that the larval supply may increase with greater water flux; however, opportunities for recruitment can be reduced in more exposed environments relative to sheltered areas. I. bicolor may require conditions that 
facilitate attachment on the shores of Espírito Santo, which may include rock crevices (ZAMPROGNO et al., 2010) or areas sheltered from wave action.

Oigman-Pszczol et al. (2004), reported that the distribution of cnidarians on infralittoral rocky shores was positively correlated to the depth due to the increased stability of environments with increasing depth. The two species of cnidarians (Palythoa sp. and Zoanthus sp.) recorded in this study occurred at higher levels (midlittoral) only at Ubu. This occurrence was most likely due to the lower observed wave impact and corresponding increased stability of the midlittoral zone in this area compared to other studies.

The shore slope may have been responsible for the differences recorded between Costa and other sites. The slope dissipates wave energy; a more inclined area sustains greater wave exposure (MURRAY et al., 2006) with the intensity of insulation, whereas the radiation is reduced in more inclined areas (BENEDETTI-CECCHI et al., 2000b).

According to SomsueB et al. (2001), the variation of algal communities in areas with different inclinations can be attributed to differences in the incident light associated with the variations in water movement. The lowest abundance of algae was observed at Costa beach, which was the steepest site with the narrowest midlittoral zone. This area likely receives less incident light, restricting the development of algae relative to Setibão and Ubu beaches (which have lower angles of inclination).

In this study, Chthamalus bisinuatus and Brachidontes spp. dominated the communities, resulting in low diversity values compared to the infralittoral communities reported by Oigman-Pszczol et al. (2004). According to these authors, diversity increased with depth, resulting in more complex communities, a trend that can be explained by the reduction in frequency of disturbance caused by physical factors.

The average diversity and richness values were higher on the exposed coast of Setibão, most likely due to greater wave exposure relative to the other study sites. CoutinHo (2002) suggested that with increasing wave action, the limits of the supralittoral and midlittoral zone are expanded, leading to increased biodiversity.

Costa beach had the lowest number of species, most likely due to less available area in comparison to the other two sites. However, the highest value of evenness was found in the same area, indicating less dominance of species in comparison with other areas.

According to the SIMPER analysis, Brachidontes spp. and Chthamalus bisinuatus were the taxa that contributed most to the similarity between group areas, demonstrating that the greater abundance of these taxa did not vary in time and space because the most abundant species within the group contribute more to the similarity (CLARKE \& WARWICK, 2001). According to the model proposed by UNDERWOOD \& CHAPMAN (2000), physical stress at higher levels of coastreduces the temporal variability of communities. These authors also proposed that in the lower levels, environmental conditions are less harsh and the number of animals is generally highly variable over time due to fluctuations in recruitment, predation, and competition. The results of this study support this hypothesis, as the differences between the studied areas in the multivariate analysis were determined according to invertebrates and algae that occurred in the lower levels on the shore.

According to community analyses of BAULCH et al. (2005), biotic responses to climate changes are not easily understood or predictable because the responses differ between the types of communities, suggesting that the disturbance history may be an important determinant in the occurrence of changes. It is necessary to have prior knowledge and temporal monitoring of benthic communities to recognize the disturbances and consequent responses to climate change.

This study demonstrated that differences among the areas, the extent of wave exposure and the slope of the shore contributed to the variability between areas. However, other factors not considered in this study, such as reproduction, recruitment and competition, may have influenced the distributions during the different seasons. Community patterns are the result of physical and biological processes that influence the growth, recruitment and mortality of organisms on temporal and spatial scales (BenedetTi-CeCCHi et al., 2000a). Thus, the zonation of benthic organisms along the rocky shore reflects the interaction of various physical and biological factors that establish precise limits of distribution (COUTINHO, 1995).

Acknowledgements. We would like to thank Dr Andrea de Oliveira Ribeiro Junqueira (UFRJ), Dr Jean-Christophe Joyeux (UFES) and Dr Mércia Barcellos da Costa (UFES) for their critical suggestions to the manuscript; colleagues of the Laboratório de Malacologia (UFES) for their assistance in the field work; Dr Cristina Aparecida Gomes Nassar (UFRJ), Dr Guilherme Henrique Pereira Filho (UFRRJ) and Dr Glória Maria de Viegas Aquije (IFES) for the macroalgae identification.

\section{REFERENCES}

Albino, J.; Paiva, D. S. \& Machado, G. M. 2001. Geomorfologia, tipologia, vulnerabilidade erosiva e ocupação urbana das praias do litoral do Espírito Santo, Brasil. Geografares 2:63-69.

AraúJo, R.; Bárbara, I.; Sousa-Pinto, I. \& Quintino, V. 2005. Spatial variability of intertidal rocky shore assemblages in the northwest coast of Portugal. Estuarine, Coastal and Shelf Science 64:658-670.

BArreto, C. C. 1999. Heterogeneidade espacial do habitat e diversidade específica: implicações ecológicas e métodos de mensuração. Oecologia Brasiliensis 7:121-153.

Baulch, H. M.; Schindler, D. W.; Turner, M. A.; Findlay, D. L.; Paterson, M. J. \& Vinebrooke, R. D. 2005. Effects of warming on benthic communities in a boreal lake: Implications of climate change. Limnology Oceanography 50(5):1377-1392.

Benedetti-Cecchi, L.; Acunto, S.; Bulleri, F. \& Cinelli, F. 2000a. Population ecology of the barnacle Chthamalus stellatus in the northwest Mediterranean. Marine Ecology Progress Series 198: $157-170$

Benedetti-Cecchi, L.; Bulleri, F. \& Cinelli, F. 2000b. The interplay of physical and biological factors in maintaining mid-shore and low-shore assemblages on rocky coasts in the north-west Mediterranean. Oecologia 123:406-417.

Boaventura, D.; Re, P.; Fonseca, L. C. \& Hawkins, S. J. 2002. Intertidal rocky shore communities of the continental Portuguese coast: Analysis of distribution patterns. Marine Ecology 23(1):69-90. 
Branch, G. M. \& Steffani, C. N. 2004. Can we predict the effects of alien species? A case-history of the invasion of South Africa by Mytilus galloprovincialis (Lamarck). Journal of Experimental Marine Biology and Ecology 300(1-2):189-215.

Breves-Ramos, A.; Jungueira, A. O. R.; Lavrado, H. P.; Silva, S. H. G. \& Ferreira-Silva, M. A. G. 2010. Population structure of the invasive bivalve Isognomon bicolor on rocky shores of Rio de Janeiro State (Brazil). Journal of the Marine Biological Association of the United Kingdom 90(6):453-459.

Casarini, L. M. \& Henriques, M. B. 2011. Estimativa de estoque do mexilhão Perna perna e da espécie invasora Isognomon bicolor em bancos naturais da Baia de Santos, São Paulo, Brasil. Boletim do Instituto de Pesca 37(1):1-11

Clarke, K. R. \& Warwick, R. M. 2001. Change in marine communities: An approach to statistical analysis and interpretation. Plymouth, PRIMER-E. 172p.

Costa, K. G. \& Nalesso, R. C. 2006. Effects of mussel farming on macrobenthic community struture in Southeastern Brazil. Aquaculture 258(1-4):655-663.

CoutınHo, R. 1995. Avaliação crítica das causas da zonação dos organismos bentônicos em costões rochosos. Oecologia Brasiliensis 1:259-271.

2002. Bentos de costões rochosos. In: Pereira, R. C. \& SoAResGomes, A. eds. Biologia Marinha. Rio de Janeiro, Interciência. p.147-157.

Crowe, T. P.; Thompson, R. C.; Bray, S. \& Hawkins, S. J. 2000. Impacts of anthropogenic stress on rocky intertidal communities. Journal of Aquatic Ecosystem Stress and Recovery 7(4):273-297.

DAVIDSON, L. C. 2005. Structural gradients in an intertidal hard-bottom community: examining vertical, horizontal, and taxonomic clines in zoobenthic biodiversity. Marine Biology 146(4):827-839.

Dethier, M. N. \& Sсносн, G. C. 2005. The consequences of scales: assessing the distribution of benthic populations in a complex estuarine fjord. Estuarine, Coastal and Shelf Science 62(12):253-270.

Domaneschi, O. \& Martins, C. M. 2002. Isognomon bicolor (C.B. Adams) (Bivalvia, Isognomonidae): primeiro registro para o Brasil, redescrição da espécie e considerações sobre a ocorrência e distribuição de Isognomon na costa brasileira. Revista Brasileira de Zoologia 19(2):611-627.

Fernandes, F. C.; Rapagnẽ, L. C. \& Bueno, G. B. 2004. Estudo da população do bivalve exótico Isognomon bicolor (C.B. Adams, 1845) (Bivalvia, Isognomonidae) na Ponta da Fortaleza em Arraial do Cabo - RJ. In: Silva, J. S. V. \& SouzA, R. C. C. L. eds. Água de Lastro e Bioinvasão. Rio de Janeiro, Interciência. p. 133-141.

Floeter, S. R.; Krohling, W.; Gasparini, J. L.; Ferreira, C. E. L. \& ZALMON, I. R. 2007. Reef fish community structure on coastal islands of the southeastern Brazil: the influence of exposure and benthic cover. Environmental Biology of Fishes 78(2):147-160.

Harley, C. D. G.; Hughes, A. R.; Hultgren, K. M.; Miner, B. G.; Sorte, C. J. B.; Thornber, C. S.; Rodriguez, L. F.; Tomanek, L. \& Williams, S. L. 2006. The impacts of climate change in coastal marine systems. Ecology Letters 9:228-241

Little, C. \& Kitching, J. A. 1996. The Biology of Rocky Shores. Oxford, Oxford University Press. 252p.

Martin, L.; Suguio, K.; Flexor, J. M. \& Arcanjo, J. D. 1996. Coasta quaternary formations of the southern part of the State of Espírito Santo (Brazil). Anais da Academia Brasileira de Ciências 68(3):389-404.

MASI, B. P. \& ZALmon, I. R. 2008. Zonação de comunidade bêntica do entremarés em molhes sob diferente hidrodinamismo na costa norte do estado do Rio de Janeiro, Brasil. Revista Brasileira de Zoologia 25(4):662-673.

Masi, B. P.; MACEDO, I. M. \& ZaLmon, I. R. 2009. Annual and spatial variation of intertidal benthic community zonation in a breakwater of Rio de Janeiro coast, south-eastern Brazil. Journal of the Marine Biological Association of the United Kingdom 89(2):225-234.

McQuaid, C. D. \& BRANCh, G. M. 1984. Influence of sea temperature, substratum and wave exposure on rocky intertidal communities: an analysis of faunal and floral biomass. Marine Ecology Progress Series 19:145-151
McQuaid, C. D. \& Lindsay, T. L. 2000. Effect of wave exposure on growth e mortality rates of the mussel Perna perna: bottom-up regulation of intertidal populations. Marine Ecology Progress Series 206:147-154.

Menconi, M.; Benedetti-Cecchi, L. \& Cinelli, F. 1999. Spatial and temporal variability in the distribution of algae and invertebrates on rocky shores in the northwest Mediterranean. Journal of Experimental Marine Biology and Ecology 233(1):1-23.

Menge, B. A. \& Sutherland, J. P. 1976. Species diversity gradients: Synthesis of the roles of predation, competition, and temporal heterogeneity. The American Naturalist 110(973):351-369.

Muene, D. 2002. Geomorfologia costeira. In: Guerra, A. J. T. \& Cunha, S. B. eds. Geomorfologia: Exercícios, técnicas e aplicações. Rio de Janeiro, Bertrant Brasil. p. 201-211.

Murray, S. N.; Ambrose, R. F. \& Dethier, M. N. 2006. Monitoring rocky shores. Berkeley, University of California Press. 248p.

Nalesso, R. C.; Joyeux, J. C.; Quintana, C. O.; Torezani, E. \& Otegui, A. C. P. 2005. Soft-bottom macrobenthic communities of the Vitória Bay estuarine System, South-Eastern Brazil. Brazilian Journal of Oceanography 53(1-2):23-38.

Nassar, C. A. G.; Souza, R. R. \& Yoneshigue-Valentin, Y. 2001. Inventário Florístico das algas marinhas bentônicas do arquipélago das três ilhas (Espírito Santo - Brasil): estudo preliminar. Leandra 16:1-10.

Oigman-Pszczol, S. S.; Figueiredo, M. A. O. \& Creed, J. C. 2004. Distribution of benthic communities on the tropical rocky subtida of Armação dos Búzios, southeastern Brazil. Marine Ecology 25(3):173-190

Oliveira-Filho, E. C. \& Mayal, E. M. 1976. Seasonal distribution of intertidal organisms at Ubatuba, São Paulo (Brazil). Revista Brasileira de Biologia 36:305-316.

Raffaelli, D. \& Hawkins, S. 1999. Intertidal Ecology. Netherlands, Kluwer Academic Publishers. 356p.

SÁ, F. S. \& Nalesso, R. C. 2000. Fauna associada aos bancos de algas na área de influência da Companhia Siderúrgica de Tubarão - CST, município da Serra, ES. Anais do V Simpósio de Ecossistemas da Costa Sul e Sudeste Brasileira, v. 2. São Paulo, Publicações ACIESP. p. 118-125.

Schoch, G. C. \& Dethier, M. N. 1996. Scaling up: The statistical linkage between organismal abundance and geomorphology on rocky intertidal shorelines. Journal of Experimental Marine Biology and Ecology 201(1-2):37-72.

Sibaja-Cordero, J. A. \& Cortés, J. 2008. Vertical zonation of rocky intertidal organisms in a seasonal upwelling area (Eastern Tropica Pacific), Costa Rica. Revista de Biología Tropical 56(4):91-104

Somsueb, S.; Ohno, M. \& KimuRA, H. 2001. Development of seaweed communities on suspended substrata with three slope angles. Journal of Applied Phycology 13(2):109-115.

Sutherland, J. P. 1974. Multiple stable points in natural communities. American Naturalist 108(964):859-873.

SzÉCHY, M. T. M. \& PAuLA, E. J. 2000. Padrões estruturais quantitativos de bancos de Sargassum (Phaeophyta, Fucales) do litoral dos Estados do Rio de Janeiro e São Paulo, Brasil. Revista Brasileira de Botânica 23(2):121-132.

Thompson, R. C.; Crowe, T. P. \& Hawkins, S. J. 2002. Rocky intertida communities: past environmental changes, present status and predictions for the next 25 years. Environmental Conservation 29(2):168-191.

UNDERWOOD, A. J. 1981. Structure of a rocky intertidal community in New South Wales: Patterns of vertical distribution and seasonal changes. Journal of Experimental Marine Biology and Ecology 51(1):57-85.

Underwood, A. J. \& Chapman, M. G. 2000. Variation in abundances of intertidal populations: Consequences of extremities of environment. Hydrobiologia 426(1):25-36.

Zamprogno, G. C.; Fernandes, L. L. \& Fernandes, F. C. 2010. Spatial variability in the population of Isognomon bicolor (C. B. Adams, 1845) (Mollusca, Bivalvia) on rocky shores in Espirito Santo, Brazil. Brazilian Journal of Oceanography 58(1):23-29

ZAR, J. H. 1996. Biostatistical Analysis. New Jersey, Prentice Hall. $662 \mathrm{p}$.

Recebido em 1 de março de 2012. Aceito em 10 de dezembro de 2012. ISSN 0073-4721

Artigo disponível em: www.scielo.br/isz 